\title{
Environmental severity promotes phylogenetic clustering in campo rupestre vegetation
}

\author{
Angela S. Miazaki ${ }^{1,2}$, Markus Gastauer ${ }^{1,3 *}$ and João A.A. Meira-Neto ${ }^{1,3}$
}

Received: May 27, 2015. Accepted: August 29, 2015

\begin{abstract}
The stress-dominance hypothesis postulates that the importance of competition in plant communities declines with increasing environmental stress while the importance of environmental filters increases. To test this hypothesis for campo rupestre vegetation, we analyzed phylogenetic diversity and community structure of angiosperm communities at two study sites within the Itacolomi State Park, Minas Gerais, Brazil. Plots representing more favorable habitats, such as those with a higher percentage of rocky outcrops that might permit the tapping of deeper water and nutrient resources as well as higher contents of clay and loam thereby increasing water and nutrient availability, show higher phylogenetic diversity and therefore lower phylogenetic clustering than plots with more sever habitats. This observation is consistent with the stress-dominance hypothesis if we assume ecological niches to be conserved within evolutionary niches. However, more comprehensive studies including tests for phylogenetic signal of ecological niches are necessary before generalizations for larger regions may be carried out.
\end{abstract}

Keywords: angiosperm community composition, environmental filtering, Faith's Index of phylogenetic diversity, Mean Nearest Taxon Index, Mean Pairwise Distance, Nearest Taxon Index, Net Relatedness Index, phylogenetic community analysis

\section{Introduction}

Different types of neotropical rocky field vegetation displace tropical forests and savannas above certain altitudes (Alves \& Kolbek 2010). Campo rupestre is a species-rich and diverse vegetation found on quartzite and sandstone outcrops or white sand soils in the highlands of southeastern Brazil (Giulietti et al. 1987; Conceição \& Giulietti 2002; Caiafa \& Silva 2005; Jacobi et al. 2008; Messias et al. 2011; Gastauer et al. 2012). Campos rupestres are exposed to intense solar radiation, high evapotranspiration, and large daily temperature variation; their soils retain little water and provide low nutrient availability (Jacobi et al. 2007). Although this diverse ecosystem is endangered by various man-made pressures (Pirani et al. 2003), little is known about the mechanisms that determine richness, taxonomic or phylogenetic diversity of these ecosystems (Mourão \& Stehmann 2007; Messias et al. 2011; Gastauer et al. 2012).

Topological variations in campo rupestre ecosystems form a small-scale relief of cracks, pontoons, valleys, rocky outcrops and depressions, each with a particular microclimate. Additionally, differences in soil composition, ranging from pure sand to completely organic layers (Benites et al. 2003), contribute to a high amount of environmental heterogeneity, resulting in a diversified mosaic of different environments (Scolforo \& Carvalho 2006). The stress-dominance hypothesis (Swenson \& Enquist 2009) postulates that the importance of competition and further density dependent factors in plant communities declines with increasing environmental stress (Grime 1977) while the importance of environmental filters increases. Environmental filters are abiotic constraints that restrict the presence of organisms within a community to individuals possessing certain morphological, physiological or phenological feature values (Simberloff 1970; Kraft et al. 2015). Competitive exclusion and further density dependent factors, in contrast, limit the coexistence of ecologically similar species with a large niche overlap (Elton 1927; Hutchinson 1957).

If we assume the ecological niche to be conserved within evolutionary lineages, closely related species are ecologically more similar. Under this assumption, environmental filters cause phylogenetic clustering, promoting the co-existence of closely related species within communities (Webb et al. 2002; Hardy 2008; Cianciaruso et al. 2009; Silva et al. 2011), while competition and further density dependent factors cause phylogenetic overdispersion (Harms et al. 2001;

\footnotetext{
${ }^{1}$ Centro de Ciências Ambientais Floresta-Escola Mario de Almeida Franco, 38200-000, Frutal, Minas Gerais, Brazil

${ }^{2}$ Universidade do Estado de Minas Gerais, Campus Frutal, 38200-000, Frutal, Minas Gerais, Brazil

${ }^{3}$ Laboratório de Ecologia e Evolução de Plantas, Departamento de Biologia Vegetal, Universidade Federal de Viçosa, 36570-000, Viçosa, Minas Gerais, Brazil

* Corresponding author: markus.gastauer@ufv.br
} 
Cavender-Bares et al. 2004). Although the assumption of niche conservatism in evolutionary lineages is discussed critically (e.g., Cavender-Bares et al. 2009; Kraft \& Ackerley 2010), there is evidence that ecological niches show phylogenetic signal (e.g., Davies et al. 2004; Díaz et al. 2004; Baraloto et al. 2012). Therefore, we expect higher phylogenetic clustering where environmental conditions are less favorable for plants, i.e., in areas with higher soil acidity, lower nutrient availability or higher sand content in the soil (Gastauer \& Meira-Neto 2014).

The aim of this study is to test if environmental severity reduces phylogenetic diversity and increases phylogenetic clustering in campo rupestre vegetation as expected by the stress-dominance hypothesis. For that, we analyzed the phylogenetic diversity and community structure of two study sites located in Itacolomi State Park in the Southern Espinhaço Mountain Range, Minas Gerais, Brazil and correlated them with different environmental variables.

\section{Methods}

\section{Study sites}

Both study sites are located in Itacolomi State Park in the municipalities of Mariana and Ouro Preto, in the southeastern region of Minas Gerais, Brazil (Fig. 1). Encompassing approximately 7,000 ha, the Itacolomi State Park covers the Serra do Itacolomi in the southern part of the Espinhaço Mountain Range that extends northwards until the Brazilian State of Bahia. The region is characterized by Köppen as a Cwb climate, with cold and dry winters as well as hot and rainy summers (Peel et al. 2007). The southern part of the Espinhaço Mountain Range in general and Itacolomi
State Park in particular have been highlighted as a local hotspot of biodiversity due to a diverse landscape and the occurrence of many endemic species (Batista et al. 2000; Dutra et al. 2014).

A mosaic of grassland vegetation, small shrubs and outcrops of quartzite rocks characterizes the study sites Calais $\left(20^{\circ} 25^{\prime} \mathrm{S}\right.$ and $\left.43^{\circ} 30^{\prime} \mathrm{W}, 1270 \mathrm{~m} \mathrm{ASL}\right)$ and Lagoa Seca $\left(20^{\circ} 26^{\prime} \mathrm{S}\right.$ and $43^{\circ} 29^{\prime} \mathrm{W}, 1600 \mathrm{~m}$ ASL). In Calais, sandy soil dominates, while Lagoa Seca is formed by clayey sands (Gastauer et al. 2015).

\section{Data collection}

In each study site, 15 plots of $10 \times 10$ m were delimited. The percentage of rocky outcrop was estimated. Soil samples were collected within each plot. From these samples, we analyzed the soil acidity $(\mathrm{pH})$, the concentration of potassium, phosphorus, magnesium, calcium and aluminum, the cation exchange capacity, the saturation of bases and aluminum (see Gastauer et al. 2015 for details).

All angiosperm species within those plots were identified (Gastauer et al. 2015). Nomenclature and classification follow that of the Missouri Botanical Garden (2015) and were carried out as suggested by Boyle et al. (2013).

\section{Phylogenetic community analysis}

We defined all species from within this study as the campo rupestre metacommunity. Species from this metacommunity were inserted into the megatree R20120829mod. new using the phylomatic function from the Phylocom 4.2 package (Webb \& Donoghue 2005). The calibration of the community phylogeny was performed by the BLADJ algorithm using exponentially distributed age estimates of Bell
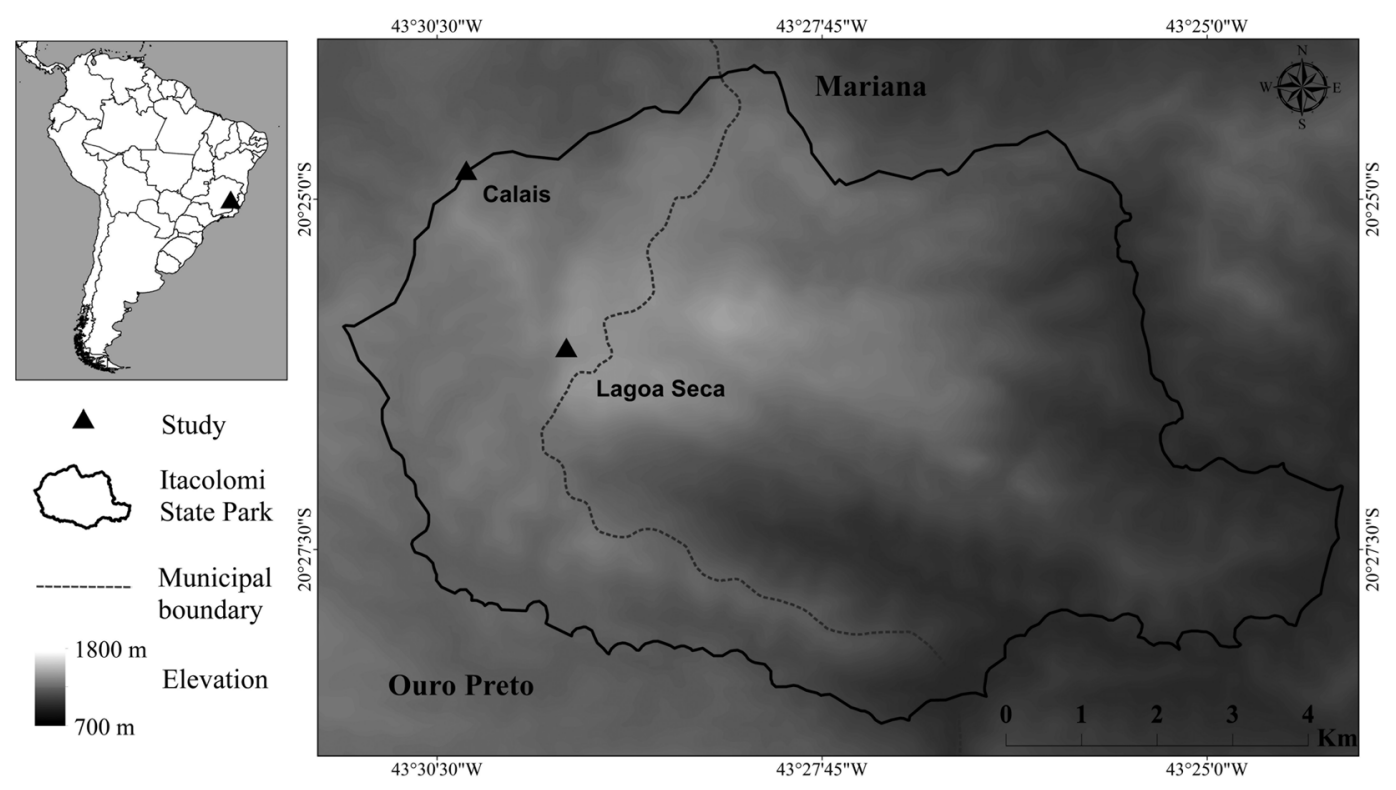

Figure 1. Localization of the study sites in relation to Itacolomi State Park and the South American continent. 
et al. (2010) with the BLADJ algorithm from Phylocom 4.2 (Webb et al. 2002), as suggested by Gastauer \& Meira-Neto (2015) (Fig. 1 in Supplementary Material).

From this metacommunity, the Faith's Index (FI) of phylogenetic diversity (Faith 1992), the Mean Pairwise Distance (MPD) and the Mean Nearest Taxon Distance (MNTD) (Webb et al. 2002) were computed for each plot using the Phylocom 4.2 package. To detect phylogenetic clustering or overdispersion, we calculated the Net Relatedness Index (NRI) and the Nearest Taxon Index (NTI) as the negative standard effective sizes of the MPD and MNTD using the unconstrained null model (Kembel \& Hubbell 2006), randomizing the composition of each plot 10,000 times. Values of zero are expected for the NRI and NTI in plots without phylogenetic structure, while positive values of these indices indicate phylogenetic clustering and negative values indicate phylogenetic overdispersion.

\section{Data analysis}

We checked normal distribution of phylogenetic diversity (FI, MPD, MNTD) and community structure indices (NRI, NTI) by the Shapiro-Wilk test. To achieve normal distribution, FI, MPD and MNTD were log-transformed using natural logarithm.

Two-tailed $t$-tests were used to identify the differences between the study sites. To detect whether the phylogenetic community structure differed significantly from zero, we used one-tailed t-tests.

To outline the influence of the environment variables of each plot, i.e., the percentage of rocky outcrops, the soil's content of small particles (i.e., sum of percentage of clay and loam), the acidity ( $\mathrm{pH})$, cation exchange capacity as well as aluminium availability, on the phylogenetic diversity and community structure, we built General Linearized Models (GLM) without any type of interactions using the "glm" command (Zuur et al. 2009) in the R Environment, version 3.1.0 (R Development Core Team 2014). We choose soil's content of small particles as a proxy for water retention (SaporettiJunior et al. 2012), while $\mathrm{pH}$, cation exchange capacity and the availability of toxic aluminium resume chemical soil properties by strong correlations with available nutrient concentrations (Gastauer et al. 2015). To detect the influence of different study sites on phylogenetic diversity and community structure, we added 'site' as a further categorical variable.

We used the dredge function from the "MuMIn" package (Bartón 2014) in the R Environment to test all possible combinations of the variables included in the global models as well as the null model. To determine which combinations of explanatory variables were the most parsimonious, we used an information-theoretic approach based on the Akaike Information Criterion of the Second Order (AICc). The best model was indicated by the lowest AICc value (Burnham et al. 2011). Nevertheless, the models that differ by, at most, two counters from the lowest AICc value were considered equally good models. From these models, we defined that one(s) with the lowest number of variables as the most parsimonious.

\section{Phylogenetic resolution}

To verify whether the lack of phylogenetic resolution in the phylogenetic hypothesis of our metacommunity influences the outcomes of phylogenetic diversity and community structure, we randomly resolved all polytomies in the phylogeny 1000 times. Each fully resolved phylogeny was calibrated with BLADJ as described above, before the indices FI, MPD, MNTD, NRI and NTI were calculated.

Indices derived from fully resolved phylogenies were correlated with that from the unresolved phylogeny as suggested by Swenson (2009). The closer the coefficients of correlation, as well as the correlations' slopes, are to 1 , the smaller the influence from the lack of phylogenetic resolution on the results and their interpretation.

\section{Results}

Altogether, we found 156 angiosperm species from 43 families. With 103 angiosperm species, species richness in Calais was higher than in Lagoa Seca (74 species). The phylogenetic diversity in Calais was higher than in Lagoa Seca (Tab. 1). Nevertheless, we detected no difference in the structure of the phylogenetic community between the study sites; the NRI and NTI values indicated phylogenetic clustering for both study sites (Tab. 1).

The best models indicate that the phylogenetic diversity measures FI, MPD and MNTD increased with the percentage of rocky outcrops. MPD and MNTD increased furthermore with the percentage of fine soil content, while FI and MPD were influenced by some differences between the study sites (Tab. 2). Due to the negative standard effective size transformation, the NRI and NTI showed inversed tendencies as MPD and MNTD.

Table 1. Comparison of the phylogenetic diversity and community structure (mean values $\pm \mathrm{SD}$ ) of two campo rupestre sites in Itacolomi State Park, southeastern Brazil. P values indicate the significance level of the difference between the study sites according to a two-tailed t test (for logtransformed values of FI, MPD and MNTD). FI is Faith's index, MPD is the Mean Pairwise Distance, MNTD is the Mean Nearest Taxon Distance, NRI is the Net Relatedness Index and NTI is the Nearest Taxon Index. Bold values indicate the NRI and NTI values that differ significantly from zero $(\mathrm{p}<0.05)$ according to a one-tailed t-test.

\begin{tabular}{lccc}
\hline Variable & Calais & Lagoa Seca & P \\
\hline FI & $2186.4 \pm 349.6$ & $1797.9 \pm 330.0$ & 0.007 \\
MPD & $219.1 \pm 11.9$ & $207.9 \pm 14.7$ & 0.030 \\
MNTD & $90.1 \pm 13.3$ & $86.2 \pm 7.9$ & 0.337 \\
NRI & $\mathbf{0 . 8 5 5} \pm \mathbf{0 . 5 0 2}$ & $\mathbf{1 . 0 7 8} \pm \mathbf{0 . 3 1 9}$ & 0.157 \\
NTI & $\mathbf{1 . 1 4 9} \pm \mathbf{0 . 7 6 1}$ & $\mathbf{1 . 3 6 9} \pm \mathbf{0 . 4 2 8}$ & 0.337 \\
\hline
\end{tabular}


Table 2. Fitting parameters, the Akaike Information Criterion of the Second Order (AICc) and the percentage of explained variance of the best model(s) explaining the phylogenetic diversity and community structure of two campo rupestre study sites from Itacolomi State Park, southeastern Brazil. ${ }^{*}$ is $p<0.05$, ${ }^{* *}$ is $p<0.01$.

\begin{tabular}{|c|c|c|c|c|c|c|c|c|c|}
\hline Variable & Intercept & Area & $\begin{array}{c}\% \\
\text { Rocky } \\
\text { outcrops }\end{array}$ & $\%$ Fine soil & $\begin{array}{l}\text { Aluminium } \\
\text { availability }\end{array}$ & $\mathrm{pH}$ & df & AICc & $\begin{array}{l}\text { Explained } \\
\text { variance }\end{array}$ \\
\hline $\log (\mathrm{FI})$ & 7.599 & $\begin{array}{l}+ \\
* *\end{array}$ & ${\underset{* \star}{3}}^{3.8010^{-3}}$ & & & & 4 & -18.5 & 42.9 \\
\hline \multirow[t]{2}{*}{$\log (\mathrm{MPD})$} & 5.207 & & $\begin{array}{c}1.0610^{-3} \\
*\end{array}$ & $\underset{* *}{5.4610^{-3}}$ & & & 4 & -82.0 & 39.1 \\
\hline & 5.359 & $\begin{array}{l}+ \\
*\end{array}$ & ${\underset{* *}{1.42} 10^{-3}}^{-3}$ & & & & 4 & -81.4 & 37.9 \\
\hline \multirow[t]{3}{*}{ Log(MNTD) } & 4.246 & & $\begin{array}{c}1.8410^{-3} \\
*\end{array}$ & $7.7810^{-3}$ & & & 4 & -45.7 & 32.2 \\
\hline & 4.425 & & ${\underset{* \star}{2.41} 10^{-3}}^{-3}$ & & & & 3 & -44.1 & 21.5 \\
\hline & 4.218 & & & $\begin{array}{c}1.0410^{-2} \\
*\end{array}$ & & & 3 & -43.8 & 20.7 \\
\hline \multirow[t]{2}{*}{ NRI } & 1.386 & $\begin{array}{l}+ \\
*\end{array}$ & ${\underset{* *}{*}}^{-3.2810^{-2}}$ & & & & 4 & 104.1 & \\
\hline & 4.656 & & $\begin{array}{c}-2.5310^{-2} \\
*\end{array}$ & $\underset{*}{-0.116}$ & & & 4 & 104.6 & 39.1 \\
\hline NTI & 1.229 & & $-\underset{* *}{-1.8510^{-2}}$ & & & & 3 & 64.0 & 30.6 \\
\hline
\end{tabular}

The FI, MPD and NRI derived from unresolved phylogeny correlated well with those derived from the resolved phylogenies; slopes lower than 0.95 or greater than 1.05 found for the MNTD and NTI showed that lacking phylogenetic resolution might over- or underestimate these indices slightly (Tab. 3). Nevertheless, correlation coefficients larger than 0.95 indicated that the indices were predicted with sufficient precision by the unresolved phylogeny.

\section{Discussion}

Calais shows higher FI and MPD than Lagoa Seca confirming findings for species richness and taxonomic diversity from previous studies (i.e., Gastauer et al. 2012). Although differences between study sites influence phylogenetic diversity measures, these increase furthermore with the percentage of rocky outcrops and/or fine soil content. Phylogenetic clustering decreases in the same direction.

Table 3. Slopes and $\mathrm{R}^{2}$ values from the regression of the phylogenetic diversity and community structure from the unresolved phylogeny with that from randomly resolved phylogenies. The table entries are mean (minimum ... maximum) values from randomly resolving the phylogenies 1000 times.

\begin{tabular}{ccc}
\hline Variable & $\mathbf{z}$ & $\mathbf{R}^{2}$ \\
\hline FI & $1.046(1.024 \ldots 1.069)$ & $0.996(0.990 \ldots 1.000)$ \\
MPD & $1.005(1.002 \ldots 1.009)$ & $1.000(0.998 \ldots 1.000)$ \\
MNTD & $1.111(1.066 \ldots 1.163)$ & $0.964(0.913 \ldots 0.990)$ \\
NRI & $0.982(0.965 \ldots 1.001)$ & $0.998(0.995 \ldots 0.999)$ \\
NTI & $0.954(0.870 \ldots 1.061)$ & $0.965(0.926 \ldots 0.991)$ \\
\hline
\end{tabular}

Strong correlations between outputs from the resolved and unresolved phylogenies indicate that the lack of phylogenetic resolution influences the results at most slightly.

While we are able to affirm that the lack of phylogenetic resolution has only small impact on the interpretation of our findings, we acknowledge that the size of the metacommunity (currently 156 species only) is inappropriate and might influence the outcomes of NRI and NTI computations. According to a recent census, 520 species from 13 well studied genera or families are already registered in Itacolomi State Park's campos rupestres; the overall richness of vascular plants is estimated to 1100 species, the majority of which are angiosperms (Gastauer \& Meira-Neto 2013). However, a checklist of all angiosperms from the Itacolomi State Park is not available at present, although it would give further valuable insights in evolutionary aspects of campo rupestre community assembly. Increasing the metacommunity beyond campos rupestres would furthermore increase our knowledge about the environmental constraints limiting the campo rupestre species pool.

Phylogenetic diversity and community structure are related to the environmental variables percentage of rocky outcrops as well as the fine soil content. Within campo rupestre vegetation (see, for example, Fig. 2 in Supplementary Material), one might easily recognize that shrubs, small trees or treelets are restricted to rocky outcrops, while gaps between rocky outcrops are covered by gramineous communities (Caiafa \& Silva 2005). This observation inspired Jacobi et al. (2007) to assume that cracks and cavities in the rocks and their surroundings provide access to deeper water and nutrients, thus reducing the severity of the environment. 
The increased content of fine soil provides more nutrients and increases water retention (Saporetti Júnior et al. 2012), also alleviating environmental harshness of campo rupestres.

The observed relation of increasing phylogenetic diversity as well as decreasing phylogenetic clustering with percentage of rocky outcrops and fine soil content indicates that phylogenetic clustering increases with environmental severity. Where environmental filters are alleviated, we found less phylogenetic clustering, thus confirming our initial hypothesis. These observations are consistent with the stress-dominance hypothesis (Swenson \& Enquist 2009; Coyle et al. 2014), when we assume ecological niches to be conserved within evolutionary lineages, so that phylogenetically more related species are ecologically more similar.

Many resource-related features in species pools from similar environments such as the Brazilian Cerrado show significant phylogenetic signal (Batalha et al. 2011; Baraloto et al. 2012; Cianciaruso et al. 2012), thus giving confidence to this interpretation. More severe environments select for ecologically more similar and phylogenetically more related species, while the importance of competition reduces, thus increasing phylogenetic clustering.

Although our data are consistent with the stress-dominance hypothesis, further processes may explain observed pattern as well (Johnson \& Stinchcombe 2007). Mayfield \& Levine (2010) postulated that competition may also lead to phylogenetic clustering, when competitive ability differences show strong phylogenetic signals, independent if niche differences are related to phylogenetic distances or not. In this scenario, superior competitors from Poaceae, Cyperaceae and Xyridaceae families may outcompete eudicot shrubs and treelets in gaps between rocky outcrops or in more sandy soils, thus increasing phylogenetic clustering in harsher environments (Godoy et al. 2014).

Therefore, more comprehensive approaches are necessary for more concluding evaluations about the stressdominance hypothesis in campo rupestre vegetation. Future studies should critically challenge the assumption of ecological niche conservation within evolutionary lineages in campo rupestre species pool for a better understanding of community assembly processes within this endangered ecosystem.

\section{Acknowledgements}

We are grateful to Maria Cristina Teixeira Braga Messias for her help during two field missions and the staff from UFOP herbarium for identifying critical specimen. We thank the Center of Environmental Research Floresta Escola Mario de Almeida Franco, the UNESCO-HidroEX Foundation, FAPEMIG, CNPq and SECTES for financial support and grants. Furthermore, we acknowledge two anonymous reviewers for their insightful comments and suggestions on earlier versions of this manuscript.

\section{References}

Alves RJV, Kolbek J. 2010. Can campo rupestre vegetation be floristically delimited based on vascular plant genera? Plant Ecology 207: 67-69.

Baraloto C, Hardy OJ, Paine CET, et al. 2012. Using functional traits and phylogenetic trees to examine the assembly of tropical tree communities. Journal of Ecology 100: 690-70.

Bartón K. 2014. Package 'MuMIn'. http://cran.r-project.org/web/packages/ MuMIn/index.html.

Batalha MA, Silva IA, Cianciaruso MV, Franc H, Carvalho GH. 2011. Phylogeny, traits, environment, and space in Cerrado plant communities at Emas National Park (Brazil). Flora 206: 949-956.

Batista JAN, Bianchetti LB, Nogueira RE, Pellizzaro KF, Ferreira FE. 2000. The genus Habenaria (Orchidaceae) in the Itacolomi State Park, Minas Gerais, Brazil. Sitientibus série Ciências Biologicas 4: 25-36.

Bell CD, Soltis DE, Soltis PS. 2010. The age and diversification of the angiosperms re-revisited. American Journal of Botany 97: 1296-1303.

Benites VM, Caiafa AN, Mendonça ES, Schaefer CE, Ker JC. 2003. Solos e vegetação nos complexos rupestres de altitude da Mantiqueira e do Espinhaço. Floresta e Ambiente 10: 76-85.

Boyle B, Hopkins N, Lu Z, et al. 2013. The taxonomic name resolution service: an online tool for automated standardization of plant names. BMC Bioinformatics 14:16.

Burnham KP, Anderson ED, Huyvaert KP. 2011. AIC model selection and multimodel inference in behavioral ecology: some background, observations, and comparisons. Behavioral Ecology and Sociobiology 65: 23-35

Caiafa NA, Silva AF. 2005. Composição florística e espectro biológico de um campo de altitude no Parque Estadual da Serra do Brigadeiro, Minas Gerais - Brasil. Rodriguésia 56: 163-173.

Cavender-Bares J, Ackerly DD, Baum DA, Bazzaz FA. 2004. Phylogenetic overdispersion in Floridian oak communities. The American Naturalist 163: 823-843.

Cavender-Bares J, Kozak KH, Fine PVA, Kembel SW. 2009. The merging of community ecology and phylogenetic biology. Ecology Letters 12: 693-715.

Cianciaruso MV, Silva IA, Batalha MA. 2009. Diversidades filogenética e funcional: novas abordagens para a Ecologia de comunidades. Biota Neotropica 9: 93-103.

Cianciaruso MV, Silva IA, Batalha MA, Gaston KJ, Petchey OL. 2012. The influence of fire on phylogenetic and functional structure of woody savannas: Moving from species to individuals. Perspectives in Plant Ecology, Evolution and Systematics 14: 205-216.

Conceição AA, Giulietti AM. 2002. Composição florística e aspectos estruturais de campo rupestre em dois platôs do Morro do Pai Inácio, Chapada Diamantina, Bahia, Brasil. Hoehnea 2: 37-48.

Coyle JR, Halliday FW, Lopez BE, Palmquist KA, Wilfahrt PA, Hurlbert AH 2014. Using trait and phylogenetic diversity to evaluate the generality of the stress-dominance hypothesis in Eastern North American tree communities. Ecography 37: 814-826.

Davies TJ, Barralough TG, Chase MW, Soltis PS, Soltis DE, Savolainen V. 2004. Darwin's abominable mystery: Insights from a supertree of the angiosperms. Proceedings of the National Academy of Sciences of the United States of America 101: 1904-1909.

Díaz S, Hodgson JG, Thompson K, et al. 2004. The plant traits that drive ecosystems: Evidence from three continents. Journal of Vegetation Science 15: 295-304.

Dutra VF, Lima LCP, Garcia FCP, Lima HC, Sartori ALV. 2014. Geographic distribution patterns of Leguminosae and their relevance for the conservation of the Itacolomi State Park, Minas Gerais, Brazil. Biota Neotropica 14: 1-15.

Elton CS. 1927. Animal ecology. London, Sidgwick and Jackson.

Faith, DP. 1992. Conservation evaluation and phylogenetic diversity. Biological Conservation 61: 1-10.

Gastauer M, Leyh W, Miazaki A, Meira-Neto JAA. 2015. Vascular plant community composition from the campos rupestres of the Itacolomi State Park, Brazil. Biodiversity Data Journal 3: e4507. doi: 10.3897/ BDJ.3.e4507. 
Gastauer M, Messias MCTB, Meira-Neto JAA. 2012. Floristic Composition, Species Richness and Diversity of Campo Rupestre Vegetation from the Itacolomi State Park, Minas Gerais, Brazil. Environment and Natural Resources Research 2: 115-128.

Gastauer M, Meira-Neto JAA. 2013. Avoiding inaccuracies in tree calibration and phylogenetic community analysis using Phylocom 4.2. Ecological Informatics 15: 85-90.

Gastauer M, Meira-Neto JAA. 2014. Interactions, environmental sorting and chance: phylostructure of a tropical forest assembly. Folia Geobotanica 49: 443-459.

Gastauer M, Meira-Neto JAA. 2015. An enhanced calibration of a recently released megatree for the analysis of phylogenetic diversity. Brazilian Journal of Biology (in press).

Giulietti AM, Menezes NL, Pirani JR, Meguro M, Wanderley MGL. 1987. Flora da Serra do Cipó, Minas Gerais: Caracterização e lista das espécies. Boletim de Botânica da Universidade de São Paulo 9: 1-151.

Godoy O, Kraft NJB, Levine JM. 2014. Phylogenetic relatedness and the determinants of competitive outcomes. Ecology Letters 17: 836-844.

Grime JP. 1977. Evidence for the Existence of Three Primary Strategies in Plants and Its Relevance to Ecological and Evolutionary Theory. The American Naturalist 111: 1169-1194.

Hardy OJ, Jost L. 2008. Interpreting and estimating measures of community phylogenetic structuring. Journal of Ecology 96: 849-852.

Harms KE, Condit R, Hubbell SP, Foster RB. 2001. Habitat associations of trees and shrubs in a 50-ha neotropical forest plot. Journal of Ecology 89: 947-959.

Hutchinson GE. 1957. Concluding remarks. Cold Spring Harbor Symposia on Quantitative Biology 22: 415-427.

Jacobi CM, Carmo FF, Vincent RC, Stehmann JR. 2007. Plant communities on ironstone outcrops - a diverse and endangered Brazilian ecosystem. Biodiversity and Conservation 16: 2185-2200.

Jacobi CM, Carmo FF, Vincent RC. 2008. Estudo fitossociológico de uma comunidade vegetal sobre canga como subsídio para a reabilitação de áreas mineradas no Quadrilátero Ferrífero, MG. Revista Árvore 32: 345-353.

Johnson MTJ, Stinchcombe JR. 2007. An emerging synthesis between community ecology and evolutionary biology. Trends in Ecology \& Evolution 22: 250-257.

Kembel SW, Hubbell SP. 2006. The phylogenetic structure of a neotropical forest tree community. Ecology 87: S86-S99.

Kraft NJB, Ackerly DD. 2010. Functional trait and phylogenetic tests of community assembly across spatial scales in an Amazonian forest. Ecological Monographs 80: 401-422.
Kraft NJB, Adler PB, Godoy O, James EC, Fuller S, Levine JM. 2015. Community assembly, coexistence and the environmental filtering metaphor. Functional Ecology 29: 592-599.

Mayfield MM, Levine JM. 2010. Opposing effects of competitive exclusion on the phylogenetic structure of communities. Ecology Letters 13: 1085-1093.

Messias MCTB, Leite MGP, Meira-Neto JAA, Kozovits AR. 2011. Life-form spectra of quartzite and itabirite rocky outcrop sites, Minas Gerais, Brazil. Biota Neotropica 11: 1-20.

Missouri Botanical Garden. 2015. http://www.tropicos.org. 10 Feb. 2015.

Mourão A, Stehmann JR. 2007. Levantamento da flora do campo rupestre sobre canga hematítica couraçada remanescente na Mina do Brucutu, Barão de Cocais, Minas Gerais, Brasil. Rodriguésia 58: 775-786.

Peel MC, Finlayson BL, McMahon TA. 2007. Updated world map of the Köppen-Geiger climate classification. Hydrology and Earth System Sciences 11: 1633-1644.

R Development Core Team. 2014. R: A language and environment for statistical computing. Vienna, R Foundation for Statistical Computing.

Saporetti Junior AW, Schaefer CEGR, Souza AL, Soares MP, Araújo DSD, Meira-Neto JAA. 2012. Influence of Soil Physical Properties on Plants of the Mussununga Ecosystem, Brazil. Folia Geobotanica 47: 29-39.

Scolforo JR, Carvalho LMT. 2006. Mapeamento e Inventário da Flora e dos Reflorestamentos de Minas Gerais. Lavras, UFLA.

Silva DM, De Paula LP, Rosatti NB, Silva IA, Cianciaruso MV, Batalha MA 2011. Os efeitos dos regimes de fogo sobre a vegetação de Cerrado no Parque Nacional das Emas, GO: considerações para a conservação da diversidade. Biodiversidade Brasileira 2: 26-39.

Simberloff DS. 1970. Taxonomic diversity of island biotas. Evolution 24: 23-47.

Swenson NG. 2009. Phylogenetic Resolution and Quantifying the Phylogenetic Diversity and Dispersion of Communities. PLoS ONE 4(2): e4390. doi:10.1371/journal.pone.0004390.

Swenson NG, Enquist BJ. 2009. Opposing assembly mechanisms in a Neotropical dry forest: Implications for phylogenetic and functional community ecology. Ecology 90: 2161-2170.

Webb CO, Ackerly DD, McPeek MA, Donaghue MJ. 2002. Phylogenies and community ecology. Annual Review of Ecology and Systematics 33: 475-505.

Webb CO, Donoghue MJ. 2005. Phylomatic: tree assembly for applied phylogenetics. Molecular Ecology Notes 5: 181-183.

Zuur AF, Ieno EN, Walker NJ, Saveliev AA. Smith G. 2009. Mixed Effects Models and Extensions in Ecology with R. New York, Springer. 